in reveral instances, and those cases in which its effects: trexe most to be dreaded, I have been undble to trace any of its usual consequences. There has been certainly, on the whole, less prostration followed by fereriah re-action, after operations under æther and chloroform, than we used to witness before the introduction of these agents.

There seems, moreorer, to be a connection between the pain felt during an operation, and that which is experienced in the wound afterwards; for you cannot hare failed to observe the comparative freedom from pain which patients enjoy for some time after operations which have been performed under the influence of wther and chloroform; they often converse on other subjects, as though there were nothing the matter with them, and when placed in bed they are at ease, and, perhaps, fall asleep.

Bepond the benefits which result from the lessening of the stiock of the operation, and the diminution of the ptin for a variable period afterwards; I am not atware that wther or chloroform exert any influence, grood or bad, upon the progress of the wound, or the mitimate recorery of the patient.

We have sometimes thought the oozing of blood from wounds, after the administration of zther, to be freater than under ordinary circumstances. It always cenced upon the application of moderate pressure, and wecondary bæmorrhage very rarely occurred.

Though I cannot but regard the introduction of ansosthetic agents as a general improvement in surgery, I hope enough has been said to show that I am not without due sense of the danger that may result from them, and of the great caution required in the employment of such very powerful agents.

\section{HISTORY OF A CASE OF POISONING BY PRUSSIC ACID.}

By J. Bampfylde Daniele, M.D., Fellow of the Royal College of Physicians, and Senior Physician to the Bath United Hospital.

(Read at the Annual Meeting of the Bath and Bristol Branch of the Profincial Medical and Surgical Association, held at Bath, Thursday, June 22ud. 1848.)

Whatever tends, either as the result of pathological observation, chemical analysis in toxicology, or through frodico-legal enquiry, to detect crime or vindicate finotence, cannot fail to be of interest to the momwits of the medical and surgical profession. It is with obfis vith therefore, that I submit to this Society an atotint of the post-mortem appearances, chemical Ginhlysis of the suspected contents of the stomach, with Gowe médico-legel obserrations on suicidal acts, committod in in irresponsible condition of mind, in reference to a caco recentry brought to my notice. Permit mo to State, thitit I was present at the examination of the body, and at the subsequent chemical analysis of the confents of the stomach, both of which were ably tha conclusively conducted at the Bath United Hospital, whth the assistance of $m y$ friend and colleague, Dr.
Davies, and our attentive House-Surgeop, Mr. Bives. I also attended the coroner's inqueist.

Forty hours after death the examination commenced. The body presented strong muscular conformation; livid patch over the posterior superior portion of the scapula extended to the coracoid process. The hande and mouth were partially closed, the usual effect when death is caused by prussic acid. There was an apoplectic resemblance in the eyes; no odour was evolved from the body; neither were there any external marks of violence. On dividing the scalp, fluid blood, perhaps more than usual, escaped; the ressels of the membranes of the brain were much injected, and the brain rather firmer than natural. On opening the lateral ventricles, the characteristic smell of prussic acid was observed by myself, Dr. Davies, Mr. Brace, and Mr. King; thert was also a small cluster of hydatids in the fluid of the rentricles. The same odour was apparent in other removed portions of the brain. The lungs were healthy, but congested. The structure of the hedrt, with it valres and carities was healthy. On reflecting back the muscles of the abdomen, there was obserred an abundant deposition of adipose tissue, and befort opening the abdominal carity, a smell of prussic acid was again perceived; with the exception of the liver partaking of a slight tawny tint, the other viscera were healthy. On removing the heart and lungs, ligatures were placed around the upper portion of the cosophagut as well as at the pyloric opening, and the stomach with its contents carefully remored.

Near the cardiac extremity the mucous membrane of the stomach was vascular. The stomach was large, and contained about six ounces of pultaceous partly-dit gested food, smelling strongly of spirit. Some of the clearer portions of its contents were filtered and sub: mitted to the action of three tests for the detection of prussic acid,-namely, "sulphate of copper, sulphate of iron and nitrate of silver." A portion of the filtered soln: tion was subjected to the sulphate of copper test, when a greenish precipitate was thrown down, which was dissolved on the addition of hydrochloric acid. To a second portion, the sulphate of iron test was applied, and on adding dilute sulphuric acid, instead of the formation of Prussian blue, the greyish precipitate produced by iron, was re-dissolved. To a third portion the nitrate of silver test was used. A heavy precipitate fell, which remained unchanged on the addition of cold nitric acid, but was immediately dissolred on raising the acid to the boiling temperature. This might perhaps be considered open to a fallacy, as the flaid previnus to being tested, had not been distilled? and probably contained animal matter. It was therefoto. deemed necessary to procure a distilled portion frow the remaining contents of the stomach, by the employ: ment of the water-bath, at a bolling temporatare: This operation was continued for several hours, and strange to say, no distilled product was collected. Sulphuric acid was added to the fluid beforo cistillation commenced.

It is probable that the cause of the prussic acid not passing over at the temperature of a water-bath, may be referred to the fatts matter contained in the ingesta. 
which on melting formed a thick layer on the surface of the fuid, and thus the vapour of the acid wasprevented ascaping.

The following letters were received in reference to this point :-

$$
\begin{aligned}
& \text { “King's College, London, } \\
& \text { “January 20, } 1848 .
\end{aligned}
$$

"My dear Sir,-I fear I cannot give you any very cortain answer to your questions; probably, however, gour test with the filtered liquid from the stomach failed from the great state of dilution of the acid. When distilled, being very rolatile, it came over in the first portions of the liquid, which thus was much more concentrated than the original solution, and so acted with the test.

"The reason usually given for employing a vapour bath is, that some organic substances in distillation furnish prussic acid though they contained none. Formiate of ammonia is one of these. I cannot say that the objection to the employment of a boiling heat meems to me a very serious one. No doubt you wuald have obtained the acid, however, by the employment of the water-bath, had yon continued the operation, the only objection to this process being the greater length of time required, which, in such cases, ought not to be allowed to have much weight.

"Beliere me, my dear Sir, "Very truly yours, "WM. ALLEN Mrhler.

\section{J. H. Brace, Esq."}

"Edinburgh, February 7, 1848.

"My dear Daniell,-In the process for obtaining hjdrocsanic acid by distillation at a rapour-bath heat, from complex organic mixtures, it is recommended to add sulphuric acid to the suspected material before distillation. Was this attended to in your proceedings ? for, if not, the poison may have existed in the form of hydrocyanate of ammonia, which may resist a mere rapour-bath heat, although ebulition may carry it over; or, may not the failure to obtain any acid by distillation without boiling have arisen from the heat not having risen sufficiently high around the retort or matrass, so that what rose from the fluid condensed above, and trickled back into the subject of analysis? for I have known this occur in other parallel processes of distillation.

"If you look again at what I have said, on the degree of heat and mode of applying it, you will see $I$ am by no means 80 positive in prescribing ebullition as you seem to have thought (seo pp. 755, 756, 4th edition,) nor is anything said derogatory to the spirit-lamp. In paint of fact, the objection to the use of a distilling heat, on the ground of risk that intestine changes may thus be produced, with the effect of forming hydrocyanic acid in complex organic mixtures, is treated as a hypothetical one, and in practice $I$ have been in the habit of disregarding it, boiling the suspected matter with a naked gas flame, without fear of fallacy. "Yours faithfully,

“ R. Cerristison."

“ 15, Bloomsbury Square, “January 17, 1848.

"My Dear Sir,-I have only time to express an opivion in farour of poisoning by prasicic acid in the case you detail, founded partly on the details of the case, and partly on the test of "the odour." "Your tests, however, are inconclusive when applied to the stomach before distillation. The best way to apply the several tests is by holding a watch-glass moistened with them over the mouth of a bottle containing the contents of the stomach, \&c. If this do not give very decided results, you must distil, at a gentlo heat, and test the distilled liquid. I would recommend you to get Mr. Taylor's "Toxicology," as containing the newest informetion, and if you have no chemist at Bath, to forward the matters for analysis in a sealed vessel, to Mr. John Bowman, or Dr. Miller, at the King's College; bat, perhaps, the evidence at the inquest will dispose of all difficulties.

"Yours very truly, " Williay A. Gor.

\section{"W. H. Brace, Esq."}

The same contents of the stomach were now submitted to the heat of a spirit-lamp, and distillation completed. A solution of the sulphate of copper boing added to a portion of the distilled finid, rendered alkaline by Liquor Potasse, the usual green precipitate was observed, which, on the addition of hydrochloric acid was rendered white. A solntion of aulphate of iron added to another portion, (aleo non. dered alkaline,) threw down a greeniah brown prem cipitate, which was re-dissolved by dilute nitric and sulphuric acid. This test was carefally repeated again and again, the same tests being applied to a solutinn of prussic acid, (rendered alkaline,) the charactorintis blue colour immediataly appeared. $A$ solution of nitrate of silver in a third portion of the distilled faid gave a dense white precipitate, which was insoluble in nitric acid, at a common temperature, but was dissolred when boiled.

The evidence of prussic acid was now establishod, although the quantity detected by the several tests was small and insufficient to account for death ; but from the time that elapsed between swallowing the poison and the examination of the body, much might have volatilized. The blood was in a fluid state, indicative of death from prussic acid.

Before entering on the defence set up on the question of medico-legal enquiry, I may briefly relate the previous history of the case :-It appears that on the evening of the 13th of last January, two females passing up Dorchester Street, observed a man lying on the ground, and on going near him found him nearly lifeless, a slight gurgling noise in his throat being the only evidence of life. They immediately sought assistance, and by the help of two policemen removed him to the United Hospital. On being receired it was found that he was dead; enquiry was made, and it was ascertained that the deceased was a surgeon, who had left a widow and seven children: the decearod had arrived from Chippenham by the night train, it which place he had stopped several hours, and drank at soveral inns; that latterly be had been in embarrasiod circumstances, which produced great depressions of mind. His mental disquietude was farther catablished by the evidence of a police constable, who, on calling at the residence of the deceased, was mot at the door 
by Mre. Spencer, who immediately exclaimed "Is he dead," and expressed her fears that she should hear of his destroying himself, every time he left home, as he soas so troubled in mind about his affairs.

A druggist, residing at Chippenham, deposed that the deceased entered his shop about eight o'clock on the evening of the 13th, and asked for an ounce or an ounce and a half of prussic acid, but did not say far what he wanted it. 'Witness handed him an onnce bottle of Scheele's hydrocyanic acid. Deceased appeared as if he had been drinking. Witness had known him for three or four years, and considered him only an occasional customer.

The Counsel for the defence having in his crossexamination endeavoured to elicit something favourable to the supposition that deceased had died of apoplexy, or some such cause, a conversation arose between him and the Coroner, whether the evidence could lead the Jury to the conclusion that the deceased had committed saicide, and if so, the Counsel would request an adjourn. ment, in order to produce evidence of unsoundness of mind. The Coroner commented on the evidence, and remarked, "Should the Jury consider death was caused by taking poison, the next point on which they ought to be satisfied, was the state of mind in which the deceased was prior to his death, and unless they had eridence that he was not sane, or was suffering from temporary derangement, the law allowed of no intermediate verdict, in what state of mind the deceased was there was no evidence to show; should there be no evidence of incanity, the jury must return a verdict of felo de se; at the same time, should they do that, it was not for him to inform them beforehand what would be the legal effect of such a verdict, as it respected property or life-insurance." The Jury having intimated that they had made up their minds as to the first point, desired an adjournment on the second, for the purpose of ascertaining by evidence, whether deceased was of sune or insane mind.

It was urged in the lefence, that the deceased was of a plethoric habit, addicted to spirit-drinking; that British brandy (having drunk some shortly before his death,) sometimes contained essential oil of almonds; that there was no evidence to shew when prussic acid was taken; that if deceased had taken an ounce of Scheele's hydrocyanic acid at the Bath Station, he could not have walked from thence to the spot where he. fell; (a case, bowever, is given in "Taylor's Medical Jurieprudence," of a person taking half an ounce of hydrocyanic acid, who had walked a similar distance;) that deceased being a surgeon, it was essential to his basiness that he should possess poisonous drugs; that very little prussic acid had been discovered in the stomach, and that little, insufficient to cause death; that the human senses were fallible; and that as odour presented no visible test, it was dangerous to place too. implicit a reliance. on it; that no bottle was found near the body, - a fact which Professor Taylor had remarked was seldom found to occur in cases of suicide from deadly poisons, so instantaueous in their paralysing effect as prussic acid is, to destroy the porer of rolition, by means of which the bottle or reseel whence it was imbibed could be fiung to a distance; that the deceased was of 'a plethoric temperament, and coustitutionally predisposed to apoplery, -a disease simulating the effects of violent poisons.

Should the Jury, however, be of opinion that deceased had poisoned himself, the next question was, whether he had committed the act in a sound state of mind or not.

Evidence was adduced that deceased had first called at a druggist's shop where he had been in the habit of purchasing all his drugs for some years; that between six and seren o'clock on the evening of the 13th, deceased entered the shop and asked for an ounce of prussic acid, Scheele's strength. It was refused him, his manner being very strange, and his answers wandering. Witness had known him to be in embarassed circum. stances, particularly during the last two years. Deceased soon left the shop. From his appearance witnese believed he was in a deranged state of mind; he was far from being affected with delirium tremens; he was low, lost, and wandering.

The brother of the deceased also stated some circumstances, which confirmed the unsettled condition of his mind, and that deceased had given a bill at two months, for some trust-money, which he had appropriated to his own use, and which became due on the day of his death.

Dr. Daniell deposed that he had seen the brain of the deceased at the post-mortem examination, and found a similar condition of the brain and ressels with that of those who had died in an unsound state of mind.

The form of insanity under which the deceased laboured, appears to me referable to that which has been termed moral munia, as distinct from insanity of the intellect. Since the time of Esquirol, all the distinguished authorities in insanity have recognized this form of lunacy. In the one the moral sentiments are perverted; in the other the reasoning powers are overturned. These two forms of insanity may be observed separately, or in combination. We may see cases of moral mania in which the reasoning powers remain unaffected; and we may see cases of purely mentat mania in which the moral sentiments and the affections are in a healthy state.

No one can observe the separate forms of moral and montal mania in a lunatic asylum without being able to trace their separate indications in mixed cuses.

We cannot shut our eyes to the real existence of cases in which the tendency to crime is a disease which no self-control on the part of the individual can arrest. What must be contended for, is the distinction in criminal cases betwen the results of rice and disease. Let the laws of the country deal with vice, but let the victim of disease, or of that peculiar condition of disorder where insane manifestation is temporary, be handed ovor to medical care and superintendence. The great object is to ascertain where vice ends, and disease begins. That the two run into each other 80 closely, that the separation is difficult, admits of no doubt; but this should not prevent medical men from following out. the truths of crime to their legitimate consequences. 
In the case I have just related, there was no evidence of intellectual mania; professional business was attended to; medical directions were correct; there was no disposition to injure others; but the res augusta domi, pecuniary embarrassment, the unhappy and soulthrilling refection of the present, as well as future, circumstances of an affectionate wife and seven belpless children, crowded on his brain. His habits vary. He was addicted to stimulating liquors; self-control is - destroyed, and on the very day when his difficulties chiefly pressed on him, he destroys himself. His self. control was lost by disease, and be required the control of otbers to guard and protect him.

It is a rery strong ground for the extension of pardon to a prisoner, where all the members of the jury, who by the terms of their oath, are compelled to find him guilty, have concurred in recommending him to mercy.

In the case of the unfortunate Annette MIeyers, not only did this recommendation run with the verdict, but wo find that the Jury, before quitting the Court, reiterated their entreaty to the Chief Baron, that the life of oue whom they term a guilty, yet deeply injured woman, may be spared.

Let $\mathrm{us}$ see the reasons the Jury assign for their recommendation.

After hearing the testimony of the witnesses delivered orally in Court, they arrived at the following conclusion :- "That she slew the man for whose murder sle stands condemned," say the Jury, " admits of no doubt. The degree of deliberation, however, and pre. meditation used by her previous to the commission of the act, materially affects its nature. To make the slaying of a man 'murder', there must be cool premeditation." The Chief Baron on the trial insisted on this point.

Now, the Jury in their letter to the Chief Baron, state that they find Annette Meyers guilty of murder, but without premeditation. They are of opinion that, up till the very hour in which the fatal act was committed, her purpose was not fixed.

"It was," say the jury, " the deliberate and atrocious contempt with which the guilty deceased treated the prisoner, -it was the last crowning act of cruelty and indignity, which drove ber into a state of phrenzy and ancontrollable passion. In that moment of phrenzy we drew forth the pistol, and laid the worthless wretch dead at her feet. That she purchned the fatal weapon under the influence of strong feeling, there is no doubt; it might have been directed against her own life, or that of the deceased. It was the merest affair of chance which of the two should fall. She accosted him in the Pari with no fixed intention of injuring him. The deliberate cruelty and determined baseness of the deceased at that moment, drove her to madness, and in her frenzy she slew him. The prorogative of mercy, therefore, is prayed to be extended to her."

I need not enter more fully on this important subject at present, as an opportunity will probably occur during the meeting of the Prorincial Medical and Surgical Association, of offering my remarks $x$ is a more matured form, and collecting valuable opinions from those enlightened professional gentlemen whose viets have been particularly directed to such subjects.

\section{CASE OF PERMANENTLY SLOW PULSE.}

Bý C. Barham, MD., Truro, Physician to the Royal Cornwall Infirmary.

(Read at the Annnal Meeting of the South-Western Branch of the Provincial Medical and Surgical Association, held at Truro, July 16th, 1847.)

In the Dublin Quarterly Journal of Medical Science, for August, 1846, there is an interesting communication from Dr. Stokes, on the connection of permanently slow pulse with repeated cerebral attacks of an apoplectic nature, though not followed by paralysis. Dr. Stokes has directed the attention of the profession to the subject as one requiring further investigation, and not hitherto much attended to, and he has himself collected only seven cases, in which the sbore combination of cardiac and cerebral phenomena was well marked. On this account I have thought it desirable to place on record, a decided instance of the co-existence of these affections, although I am not furnished with the precise results of any physical examination of the heart during life, neither was a cadaveric inspection permitted.

A lady, aged 69, the mother of a large family, having risen from her chair, and moved towards the bed, fell forward on it, and almost instantly expired. She was at the time apparently recovering steadily, though slowly, from an attack of hemiplegia, following an apoplectiform seizure, which had occurred about six weeks before. Her usual pulse was 28 in the minute, but it had risen on the day of her death eight or ten beats, a circumstance which excited some apprehension in the mind of her medical attendant, who had visited her some hours before the fatal event.

The first decided cerebral attack occurred in Sept., 1834. Before this she was a remarkably good walker, and took a great deal of exercise in the garden, but from that date she was obliged to discontinue walking and stooping, which produced an uneasy feeling about the heart. The affection was decidedly apoplectic in its character, and life was considered in great danger for some hours, but the recovery was afterwards rapid and perfect, and there was no paralysis. A similar attack occurred in the following year, and another about Christmas, 1841. Sickness and gastric disturbance attended them all.

There were thus, altogether, at least four seizures of this kind. But in the intervals between these, her family were many times alarmed by the occurrence of what they designate "fainting fits," which came on especially after dinner, when she would often appear quite oppressed, and sometimes talk in rather an incoherent manner. This was more particularly the case towards the latter part of her life, when cupping on the nucha, which had always relieved her, was repeated about once in three months. On the last twa or three occasiong, howerer, the benefit derived from it was rery transient; the blood was always thick and flowed tardily. She was often obliged to have recourse to aperieuts, but their action produced no effect on the head symptoms, or rather seemed to aggravate them. The appetite was always good. Cold woather increased the affection of the head, and occasioned her severe suffering. In her latter years the breath became very 